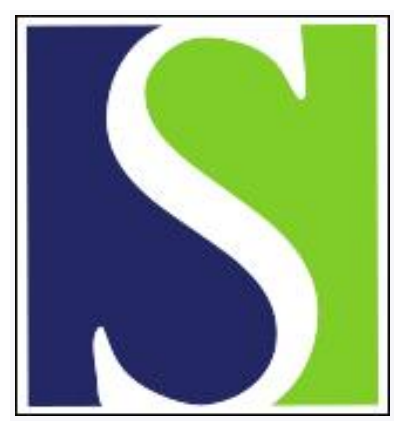

Scand J Work Environ Health 1980;6(3):206-215

https://doi.org/10.5271/sjweh.2614

Issue date: Sep 1980

Study of some hepatic effects (induction and toxicity) caused by occupational exposure to styrene in the polyester industry. by Hotz P, Guillemin MP, Lob M

Key terms: exposure; hepatic effect; hepatotoxicity; induction; metabolite; occupational exposure; polyester industry; styrene; toxicity

This article in PubMed: www.ncbi.nlm.nih.gov/pubmed/6937826

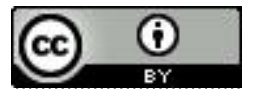




\title{
Study of some hepatic effects (induction and toxicity) caused by occupational exposure to styrene in the polyester industry
}

\author{
by Philippe Hotz, MD, Michel P Guillemin, PhD, Marc Lob, MD ${ }^{1}$
}

\begin{abstract}
HOTZ P, GUILLEMIN MP, LOB M. Study of some hepatic effects (induction and toxicity) caused by occupational exposure to styrene in the polyester industry. Scand $j$ work environ health 6 (1980) 206-215. This study describes an occupational health survey carried out in the polyester industry in order to investigate the hepatic effects caused by exposure to styrene. Fifty-seven workers underwent a medical examination. They were submitted to blood and urine sampling for the determination of the degree of exposure, by the analysis of urinary mandelic and phenylglyoxylic acids (styrene metabolites), and the intensity of induction and/or hepatic effects, by the analysis of urinary glucaric acid and plasma enzyme activities (gamma glutamyl transferase, ornithine carbamoyl transferase, alanine aminotransferase, and aspartate aminotransferase). The results showed that styrene does not give rise to measurable autoinduction. With regard to the hepatic tests, exposure to styrene caused an increase in the plasma enzyme activities, a phenomenon illustrating a possible damaging effect on liver cells. This effect appears with exposure below $100 \mathrm{ppm}$ (time-weighted average).
\end{abstract}

Key terms: exposure, hepatotoxicity, metabolites.

Styrene (vinyl-benzene) is considered to be a hydrocarbon of relatively low toxicity. However, results of studies of its long-term effects on the hepatic cell are diverse. In this study, we have attempted to find possible hepatotoxic or inductive effects caused by occupational exposure to styrene.

"Enzyme induction is an adaptive increase in the number of molecules of a specific enzyme secondary either to an increase in its rate of synthesis or to a decrease in its rate of degradation [p 523]" (3). It is interesting to detect an inductive effect caused by styrene for two reasons. First styrene could induce, ie, accelerate, its own metabolism (autoinduction), which

1 Institute of Occupational Medicine and Industrial Hygiene, University of Lausanne, Lausanne, Switzerland.

Reprint requests to: Prof Marc Lob, Institut Universitaire de Médecine du Travail et d'Hygiène Industrielle, rue César-Roux 18, CH-1005 Lausanne, Switzerland. would thus have to be taken into account when biological monitoring is interpreted $(11,13,25)$. Second an induction test could be used as an exposure index since the inductive effect often precedes the toxic effect (20).

Currently there is no universal indicator of enzyme induction by man which is both easy to carry out and wholly reliable; therefore we had to look to the literature $(10,14,18,20)$ for the most suitable induction test for the purpose of this study. We chose to measure the urine concentration of glucaric acid.

With regard to the hepatotoxic effects of styrene in occupationally exposed workers, opinions vary $(8,15,17)$. These different opinions are at least partly due to the following reasons: the variable composition of the groups of exposed and reference workers, insufficient knowledge of individual styrene exposure levels, differences in the examination methods, no exclusion of subjects with liver disease 
or drug consumption (which could affect the biological tests).

In order to eliminate these causes of error to the greatest extent possible, we examined a homogeneous group of healthy male workers, whose individual exposure was estimated from the measurement of the urinary concentration of mandelic and phenylglyoxylic acids. We measured the activities of aspartate aminotransferase (ASAT, 2.6.1.1), alanine aminotransferase (ALAT, 2.6.1.2), ornithine carbamoyl transferase (OCT, 2.1.3.3) and gamma glutamyl transferase ( $\gamma \mathrm{GT}, 2.3 .2 .2)$. It is to be noted that the latter two enzymes appear to be more suitable than the transaminases for detecting chronic hepatic disorders (1, 2, 4, $21,22,23,28)$. Other advantages are that they can be stored longer and are much less sensitive to hemolysis and lipemia.

A general outline of the study and a complete description of the different aspects of the medical survey have been given elsewhere $(7,9)$.

\section{Subjects and methods}

\section{Exposed group}

The exposed group consisted of 57 men selected from a group of 94 workers, all exposed to styrene. These 57 subjects fulfilled the following selection criteria: (i) no hepatic or renal disease found in a clinical examination and (ii) no drug consumption.

\section{Reference group}

For the estimation of OCT activity and the urinary elimination of glucaric acid, reference values were necessary. We obtained these by examining two different groups composed of, respectively, 118 persons (for the OCT) and 36 (for the glucaric acid). In each case, we studied apparently healthy people. Details of the selection of these groups and the setting of the reference values have been given elsewhere (9). The samples from the reference groups were analyzed at the same time as those from the exposed workers.

\section{Clinical examination and occupational history}

Each worker underwent a clinical exami- nation voluntarily. Alcohol consumption was estimated according to the questions proposed by Rollason et al (23). The creatinine clearance was calculated according to the data given by Kampmann et al (12). Obesity was evaluated according to the Broca index (weight in kilograms/height in centimeters minus 100).

\section{Blood}

Heparinated tubes were used for the blood. Blood sampling was done while the subjects were seated, in the morning before the coffee break or before the lunch to prevent lipemia.

The plasma was centrifuged as quickly as possible, and in every case within $6 \mathrm{~h}$ of sampling. Plasma specimens were stored at $4^{\circ} \mathrm{C}$ (enzyme activity measurements) or frozen, at the latest, within $12 \mathrm{~h}$ of sampling (creatinine measurements). The samples used to measure the transaminase activities were not kept longer than $2-3 \mathrm{~d}$, those for OCT and $\gamma \mathrm{GT}$ activity measurements not longer than a week, and those for blood creatinine measurements not more than three weeks.

The measurement methods and reference values are given in table 1. As the values for "normal" enzyme activity vary widely (eg, from 3 to $10 \mathrm{U}$ for OCT, but from 0 to $28 \mathrm{U}$ for $\gamma \mathrm{GT}$ ), all enzyme activities were expressed as the percentage of their respective upper reference value to simplify the comparisons.

\section{Urine samples}

Ninety percent of the glucaric acid analyses were done on urine samples taken in the morning before the beginning of the workshift, the remaining $10 \%$ on samples taken during the day. The samples were frozen until analysis, which was carried out a maximum of ten weeks later. The presence of mandelic and phenylglyoxylic acids does not interfere with glucaric acid determination.

An analysis of the protein content of a morning urine sample and a complete urine examination, together with a second analysis of the protein content of a sample taken between 0900 and 1500 , were carried out within a few hours of the sampling.

The mandelic and phenylglyoxylic acid content of three different urine samples 
taken between 0900 and 1500 , were carried out within a few hours of the sampling.

The mandelic and phenylglyoxylic acid content of three different urine samples taken over two consecutive days was estimated. These samples were taken (a) on day 1 before the beginning of the workshift, (b) on day 1 at the end of the workshift, and (c) on day 2 before the beginning of the workshift.

To estimate the individual degree of exposure to styrene, the following para-

Table 1. Measurement methods and reference values.

\begin{tabular}{|c|c|c|}
\hline Test & Method used & Reference values \\
\hline $\begin{array}{l}\text { Ornithine carbamoyl } \\
\text { transferase }\end{array}$ & $\begin{array}{l}\text { Bio-Mérieux (France, } \\
\text { number } 6-1451 \& \text { \& } 6-147 \text { 1) } \\
\text { slightly modified }\end{array}$ & Up to $10 \mathrm{U}$ \\
\hline Aspartate aminotransferase ${ }^{a}$ & $\begin{array}{l}\text { Boehringer automated method } \\
\text { (Mannheim) number } 124508\end{array}$ & Up to $20 \mathrm{U}$ \\
\hline Alanine aminotransferasea & $\begin{array}{l}\text { Boehringer automated method } \\
\text { (Mannheim) number } 124656\end{array}$ & Up to $17 \mathrm{U}$ \\
\hline Gamma glutamyl transferasea & $\begin{array}{l}\text { Boehringer automated method } \\
\text { (Mannheim) number } 125594\end{array}$ & $\begin{array}{l}\text { Up to } 28 \mathrm{U} \text { for males and } 18 \mathrm{U} \\
\text { for females }\end{array}$ \\
\hline Plasma creatinine & $\begin{array}{l}\text { Boehringer automated method } \\
\text { (Mannheim) number } 124192\end{array}$ & $<106 \mu \mathrm{mol} / \mathrm{l}$ for males \\
\hline Glucaric acid & Simmons et al (27) & $\begin{array}{l}31.4 \pm 20.0 \mu \mathrm{mol} / 24 \mathrm{~h} \text { (9) or } \\
39.0^{\mathrm{b}} \pm 17.9 \mu \mathrm{mol} / 24 \mathrm{~h}(27)\end{array}$ \\
\hline $\begin{array}{l}\text { Creatinine in urine } \\
\text { Mandelic acid and } \\
\text { phenylglyoxylic acid }\end{array}$ & $\begin{array}{l}\text { Zender \& Falbriand (29) } \\
\text { Guillemin \& Bauer (5) }\end{array}$ & - \\
\hline $\begin{array}{l}\text { Proteins, blood, glucose, } \\
\text { urobilinogene, cetonic } \\
\text { compounds, pH }\end{array}$ & $\begin{array}{l}\text { Multistix (Ames-Diagnostika), } \\
\text { Combur }{ }^{8} \text { (Boehringer Mannheim } \\
\text { number } 10 \text { 081) }\end{array}$ & - \\
\hline
\end{tabular}

a Measurements carried out by the Central Laboratory of the University's Cantonal Hospital in Lausanne (CHUV).

b Nonsignificant difference; $\mathbf{N}=26$ in both cases.

Table 2. Normality tests of the distributions.

\begin{tabular}{|c|c|c|c|}
\hline \multirow[b]{2}{*}{ Variable } & \multirow[b]{2}{*}{ Abbreviation } & \multicolumn{2}{|c|}{ p-value } \\
\hline & & $\begin{array}{l}\text { Before loga- } \\
\text { rithmic trans- } \\
\text { formation }\end{array}$ & $\begin{array}{l}\text { After logarithmic } \\
\text { transformation }\end{array}$ \\
\hline \multicolumn{4}{|l|}{ Mean of the total metabolite } \\
\hline concentration on days $1 \& 2$ & TM3 & 0.09 & 0.83 \\
\hline Mandelic acid (end of shift) & MAES & 0.02 & 0.80 \\
\hline Ornithine carbamoyl transferase & OCT & 0.11 & 0.60 \\
\hline Aspartate aminotransferase & ASAT & 0.06 & 0.25 \\
\hline Alanine aminotransferase & ALAT & 0.04 & 0.73 \\
\hline Gamma glutamyl transferas $\Theta$ & $\gamma \mathrm{GT}$ & 0.31 & 0.63 \\
\hline Glucaric acid $(\mu \mathrm{mol} / \mathrm{l})$ & - & 0.13 & - \\
\hline Glucaric acid $(\mu \mathrm{mol} / 24 \mathrm{~h})$ & GA & 0.07 & - \\
\hline Glucaric acid $(\mu \mathrm{mol} / \mathrm{l} / \mathrm{kg})$ & - & 0.47 & 一 \\
\hline Glucaric acid ( $\mu \mathrm{mol} / \mathrm{mmol}$ creatinine) & - & 0.78 & 一 \\
\hline Plasma creatinine & - & 0.24 & - \\
\hline Creatinine clearance & - & 0.99 & - \\
\hline Broca index & 一 & 0.65 & 一 \\
\hline
\end{tabular}

a The normality of the distribution was tested with the test of Kolmogorov-Smirnov. The p-value represents the significance level for the difference between the theoretical and observed distribution. 
meters were used: (i) mandelic acid concentration in a urine sample taken on day 1 at the end of the workshift (MAES) and (ii) total metabolite concentration (TM) in urine samples taken in the morning before the beginning of the workshift.

The TM, ie, the sum of the mandelic and phenylglyoxylic acid concentrations, was determined in the urine samples taken on day 1 (TM1) and day 2 (TM2). The TMs correlate better with styrene exposure than the MAES (6). Treatment and conservation of the urine samples have been discussed in another report (5).

Internal quality control was carried out according to the usual rules (22).

Statistics were calculated with standard programs for the chi-square, Pearson or Spearman correlation coefficient, the one- to threeway variance analysis, and the Kolmogorov-Smirnov test (19). Nonsignificance was at the $5 \%$ probability level. When the deviation from a normal distribution was large, a logarithmic transformation was performed (table 2), but this procedure hardly changed the significance level of the results. OCT activity measurements were carried out in one laboratory and the $\gamma$ GT, ASAT and ALAT activity measurements in another. Neither of these laboratories was aware of the other's re- sults, and the urinary metabolite concentrations were known only after the clinical and paraclinical examinations had been completed.

\section{Results}

\section{General remarks}

Industrial hygiene surveys showed that, with the exception of styrene exposure, the occupational environment was comparable in the ten factories visited. In addition, the occupational history did not reveal any particular element likely to bias the results of our study. Symptoms and signs pathologically related to the digestive and urinary system were looked for. The results for the digestive system are presented in table 3 . In relation to the urinary system (history of renal disease, isolated urinary symptoms, complete urinalysis, plasma creatinine and calculated clearance), there was no abnormality likely to alter the results.

The distribution of workers in the different classes formed according to the duration of exposure is given in table 4 .

An examination of these results shows that the group under study was fairly homogeneous and that neither styrene

Table 3. Clinical examination of the digestive system.

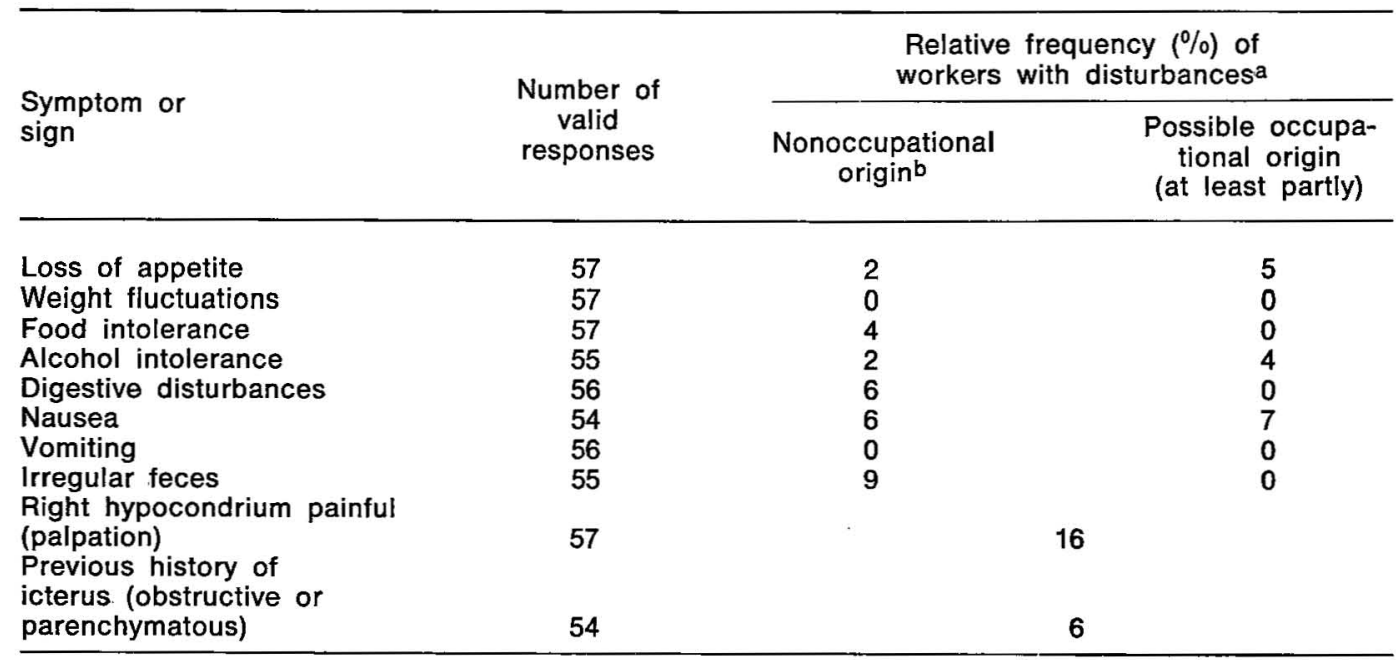

a In every case, the total number of valid responses and the relative frequency (number of cases as the percentage of the absolute number of responses or valid examinations) is given.

b On the basis of occupational history. 
Table 4. Duration of exposure to polyester. (Number of valid responses 57 )

\begin{tabular}{lc}
\hline $\begin{array}{l}\text { Duration of } \\
\text { exposure } \\
\text { rounded to } \\
\text { nearest num- } \\
\text { ber of years }\end{array}$ & $\begin{array}{c}\text { Relative frequency of workers } \\
\text { in each class }(\%)\end{array}$ \\
\cline { 2 - 2 } & $\begin{array}{c}\text { Present duration "Total" duration } \\
\text { of exposure } \\
\text { in factory of exposurea }\end{array}$
\end{tabular}

\begin{tabular}{crr}
0 & 14 & 12 \\
1 & 19 & 17 \\
2 & 9 & 7 \\
3 & 5 & 4 \\
4 & 9 & 9 \\
5 & 7 & 7 \\
$6-10$ & 32 & 30 \\
$11-20$ & 5 & 14 \\
\hline
\end{tabular}

a Total duration of exposure $=$ total number of years (calculated from the whole occupational life) of exposure in the polyester industry.

resorption, metabolism and excretion nor the biological tests can be affected by sex differences, drug consumption, or hepatic or renal diseases. It is to be noted that more than $50 \%$ of the workers stay less than $5 \mathrm{a}$ in the polyester industry.

The main statistical parameters are given in table 5 .

\section{Urinary concentrations}

Mandelic and phenylglyoxylic acid. The workers excreted, on an average, the same amount of metabolites on day 1 as on day 2 (nonsignificant difference between both days). In addition, the individual TM1 and TM2 correlated well $(\mathrm{N}=48, \mathrm{r}=0.82, \mathrm{p}$ 0.01 ). We have therefore calculated the average (TM3) of these two individual values. This average and the MAES have been used as the exposure index. From table 5 it can be seen that the degree of exposure varied considerably.

A preliminary evaluation (7) showed that the amount of styrene inhaled is the determining factor in the formation and elimination of mandelic and phenylglyoxylic acid. The relationship between the creatinine clearance (calculated) and the amount of metabolites excreted (corrected or not by the creatinine) was slightly significant, but the correlation coefficients were too small to be of statistical importance (at the most: $N=44$, $r=-0.26, p<0.05)$. Last there was no statistically significant relationship between TM3 or MAES and nationality, amount of tobacco or alcohol consumption, present or total length of exposure, or the Broca index.

\section{Glucaric acid}

Opinions vary as to what unit should be used to express glucaric acid elimination. We have thus systematically used the following units in the statistical evaluations, micromoles per liter, micromoles per liter per kilogram of body weight, micromoles per micromole of creatinine, and micromoles per $24 \mathrm{~h}$. In the last case, the calculations were based on the following formula: excretion in $\mu \mathrm{mol} / 24 \mathrm{~h}=(\mathrm{X} / \mathrm{Y}) \times$ $\mathrm{Z}$, where $\mathrm{X}$ is the glucaric acid concentration in micromoles per liter, $\mathrm{Y}$ the creatinine concentration $(\mathrm{mol} / \mathrm{l})$ in the urine sample used to establish the glucaric acid concentration, and $\mathrm{Z}$ the theoretical amount (mol) of creatinine eliminated during $24 \mathrm{~h}$, taking into account sex, age and weight (12). The results vary only very slightly, as a function of the unit chosen, and, as the unit micromoles per $24 \mathrm{~h}$ is theoretically the most correct, the results have hereafter been expressed in this unit only.

The different variance analyses (uniand multivariate) did not show a significant statistical relationship between the excretion of glucaric acid and the consumption of tobacco or alcohol, the present or total length of exposure, or the degree of exposure.

\section{Study of blood enzyme activity}

From the results of the correlation coefficients and of the bivariate (exposure level and alcohol consumption) or trivariate (exposure level, alcohol consumption, length of exposure), it was seen, first, that the OCT and ALAT activities correlated better than the $\gamma \mathrm{GT}$ and, especially, the ASAT activities with the degree of styrene exposure. Second, the correlation between the TM3 and the enzyme activities was much better than the correlation between the MAES and the enzyme activities (table 6). It should be remembered that the exposure was shown to correlate better with the TM3 than with the MAES (6). Third, the 
degree of exposure had a greater effect after correction for alcohol consumption. This phenomenon, described by Lorimer et al (17) in their study of $\gamma \mathrm{GT}$ activity in workers exposed to styrene, was much less pronounced in our study for this enzyme than for the OCT and ALAT activity. Fourth, if the total duration of exposure is replaced by the Broca index, the OCT variance improves slightly (from 30 to $36 \%$ ). Finally, the relationships between enzyme activity and exposure duration (present or total) were never significant. The main results of the variance analysis are shown in table 7.

The effect of styrene on the hepatic tests can also be seen in a comparison of two subgroups of workers exposed to different solvent concentrations (table 8 ). The subjects of subgroup $\mathrm{Al}$ excreted less than $0.292 \mathrm{~mol} / \mathrm{mol}$ of creatinine $(390 \mathrm{mg}$ of TM3/g of creatinine), which corresponds

Table 5. Means and standard deviations of parameters measured for the workers.

\begin{tabular}{|c|c|c|}
\hline Variable & $\begin{array}{l}\text { Number of } \\
\text { workers }\end{array}$ & Mean $\pm S D$ \\
\hline Age (a) & 57 & $35.5 \pm 10.2$ \\
\hline Weight (kg) & 57 & $72.0 \pm 10.0$ \\
\hline Height (m) & 57 & $1.72 \pm 0.1$ \\
\hline Broca index & 57 & $1.01 \pm 0.12$ \\
\hline Specific gravity of urine & 53 & $1,021.7 \pm 3.2$ \\
\hline Creatinine (plasma) $(\mu \mathrm{mol} / \mathrm{l})$ & 52 & $91.9 \pm 12.6$ \\
\hline Clearance $\left(\mathrm{ml} / \mathrm{mn}\right.$ per $\left.1.73 \mathrm{~m}^{2}\right)$ & 52 & $99.8 \pm 14.6$ \\
\hline TM3 $[\mathrm{mmol} / \mathrm{mol} \text { of creatinine }(\mathrm{mg} / \mathrm{g} \text { of creatinine })]^{\mathrm{a}}$ & 48 & $174.2 \pm 2.0(232.8 \pm 2.7)$ \\
\hline MAES $\left[\mathrm{mmol} / \mathrm{mol}\right.$ of creatinine $(\mathrm{mg} / \mathrm{g} \text { of creatinine) }]^{b}$ & 48 & $343.0 \pm 2.9(461.3 \pm 3.9)$ \\
\hline $\begin{array}{l}\text { Glucaric acid }(\mu \mathrm{mol} / 24 \mathrm{~h}) \\
\text { Ornithine carbamovl transferase }(\% \text { of "normal" }\end{array}$ & 55 & $48.4 \pm 35.5$ \\
\hline $\begin{array}{l}\text { Ornithine carbamoyl transferase ( } \% \text { of "normal" } \\
\text { upper limit) }\end{array}$ & & \\
\hline $\begin{array}{l}\text { upper limit) } \\
\text { Aspartate aminotransferase ( } \% \text { of "normal" }\end{array}$ & 56 & $63.3 \pm 17.3$ \\
\hline $\begin{array}{l}\text { upper limit) } \\
\text { Alanine aminotransferase ( } \% \text { of "normal" }\end{array}$ & 55 & $45.9 \pm 14.0$ \\
\hline $\begin{array}{l}\text { upper limit) } \\
\text { Gamma glutamyl transferase ( } \% \text { of "normal" }\end{array}$ & 55 & $44.6 \pm 24.7$ \\
\hline upper limit) & 57 & $60.0 \pm 39.2$ \\
\hline
\end{tabular}

a Geometric mean of the total average metabolite concentration before the beginning of the workshift. The arithmetric mean ( \pm SD) was $275.3 \pm 266.3 \mathrm{mmol} / \mathrm{mol}$ of creatinine $(367.8 \pm 355.8$ $\mathrm{mg} / \mathrm{g}$ of creatinine).

b Geometric mean of the mandelic acid at the end of the workshift. The arithmetric mean ( \pm SD) was $734.2 \pm 946.1 \mathrm{mmol} / \mathrm{mol}$ of creatinine $(987.4 \pm 1,272.4 \mathrm{mg} / \mathrm{g})$.

Table 6. Correlations (Spearman) between the degree of exposure and enzyme activities.

\begin{tabular}{|c|c|c|c|c|}
\hline & $\begin{array}{c}\text { Ornithine } \\
\text { carbamoyl } \\
\text { transferase }\end{array}$ & $\begin{array}{c}\text { Aspartate } \\
\text { amino- } \\
\text { transferase }\end{array}$ & $\begin{array}{c}\text { Alanine } \\
\text { amino- } \\
\text { transferase }\end{array}$ & $\begin{array}{c}\text { Gamma glutamyl } \\
\text { transferase }\end{array}$ \\
\hline \multicolumn{5}{|c|}{$\begin{array}{l}\text { Total metabolite } \\
\text { concentrationa }\end{array}$} \\
\hline $\begin{array}{l}\mathrm{r} \\
\mathrm{p}\end{array}$ & $\begin{array}{c}0.42 \\
47 \\
0.002\end{array}$ & $>\overline{0.1}$ & $\begin{array}{c}0.40 \\
46 \\
0.003\end{array}$ & $\begin{array}{r}0.30 \\
48 \\
.02\end{array}$ \\
\hline $\begin{array}{c}\text { Man } \\
r \\
N \\
p\end{array}$ & $\begin{array}{c}(0.23) \\
47 \\
(0.06)\end{array}$ & $>\overline{0}$ & $\begin{array}{c}(0.19) \\
46 \\
(0.10)\end{array}$ & $>0 . \overline{-}$ \\
\hline
\end{tabular}

a Urine specimens taken before the beginning of the workshift, average of two consecutive days. b Urine specimens taken at the end of the workshift on day 1. 
Table 7. Variations of enzyme activities as a function of the degree of exposure, alcohol consumption and the Broca index. (OCT $=$ ornithine carbamoyl transferase, ALAT $=$ alanine aminotransferase).

\begin{tabular}{|c|c|c|c|c|c|c|}
\hline $\begin{array}{c}\text { I } \\
\text { Enzyme }\end{array}$ & $\begin{array}{c}\text { II } \\
\text { General } \\
\text { mean of } \\
\text { enzyme } \\
\text { activity } \\
(\mathrm{N}=44)\end{array}$ & $\begin{array}{c}\text { III } \\
\text { Effecta of } \\
\text { degree of } \\
\text { exposure } \\
\text { (p) }\end{array}$ & $\begin{array}{c}\text { IV } \\
\text { Effecta of } \\
\text { alcohol } \\
\text { consumption } \\
\text { (p) }\end{array}$ & $\begin{array}{c}V \\
\text { Effecta of } \\
\text { Broca index } \\
(p)\end{array}$ & $\begin{array}{c}\text { VI } \\
\text { Main effects } \\
p \text { and } \\
\text { variance } \\
\text { explained }\end{array}$ & $\begin{array}{c}\text { VII } \\
\text { Interactions }\end{array}$ \\
\hline OCT & $61.7 \%$ & $\begin{array}{l}1:-10.4 \\
2:+5.9 \\
3:+5.9 \\
(0.003)\end{array}$ & $\begin{array}{c}1:+4.4 \\
2:-2.8 \\
\text { not significant }\end{array}$ & $\begin{array}{l}1:+4.4 \\
2:-4.1 \\
(0.04)\end{array}$ & $\begin{array}{l}0.001 \\
36 \%\end{array}$ & not significant \\
\hline ALAT & $40.7 \%$ & $\begin{array}{l}1:-9.1 \\
2:+0.9 \\
3:+8.2 \\
(0.07)\end{array}$ & $\begin{array}{c}1:+6.0 \\
2:-3.6 \\
\text { not significant }\end{array}$ & $\begin{array}{l}1:-0.9 \\
2:+0.9 \\
\text { not signific }\end{array}$ & $\begin{array}{ll} & 0.10 \\
& 19 \% \\
& \end{array}$ & not significant \\
\hline
\end{tabular}

Column II: mean recalculated from the logarithmic mean for the 44 subjects with no missing data in the variance analysis. The units are expressed as the percentage of the upper limit of the reference values.

Column III: the degree of exposure [estimated by the mean of the total metabolite concentration on days 1 and 2 (TM3)] increases from subgroup 1 to subgroup 3 . Each subgroup contained one-third of the total exposed group. Subgroup $1: \mathrm{TM} 3<0.112 \mathrm{~mol} / \mathrm{mol}$ of creatinine; subgroup 3: $\geqslant$ TM3 0.273 $\mathrm{mol} / \mathrm{mol}$ of creatinine. The results shown in columns III, IV, and V indicate the fluctuations in activity compared with the general mean on one hand, and the significance level (in parentheses) for the effect of this factor as an isolated case on the other.

Column IV: subgroup 1, irregular alcohol consumption; subgroup 2, daily consumption.

Column V: the limit between these two subgroups corresponded with the median.

Column VI: shows the significance of the three factors taken together and the percentage of the total variance of enzyme activity explained by these three factors as a whole.

a Effect means the difference between the considered group (1,2 and 3 or 1 and 2) and the general mean. For example, the workers in the lowest exposure group would theoretically have an OCT activity of $51.3 \%$ and those in the highest exposure group a corresponding value of $67.6 \%$. This difference is significant at $p=0.003$.

to a styrene exposure of less than $50 \mathrm{ppm}$. In subgroup A2, the workers excreted more than $0.292 \mathrm{~mol} / \mathrm{mol}$ of creatinine $(390$ $\mathrm{mg}$ of TM3/g of creatinine), and two-thirds of them less than $0.599 \mathrm{~mol} / \mathrm{mol}$ of creatinine $(800 \mathrm{mg} / \mathrm{g}$ of creatinine) (which corresponds to a styrene exposure of 50$100 \mathrm{ppm})$. The results of the hepatic tests were, on the average, better in subgroup A1 than in A2.

A comparison of the distribution of the enzyme activities of both subgroups showed that the whole distribution for OCT, ALAT and $\gamma$ GT was shifted towards higher values from subgroup $\mathrm{A} 1$ to $\mathrm{A2}$, which is illustrated for OCT in fig 1. This shift shows that the higher average activities of the latter group were due to a tendency of the entire group and they were not influenced by the small minority of workers more significantly affected. Therefore, a higher degree of exposure to styrene would give rise to increased enzyme activities. Although there were not many enzyme activities outside of the reference range (pathological values), the possibility that styrene is hepatotoxic cannot be ruled out for two reasons. First of all, a selection of the workers with the better liver tests, as described by Zielhuis (30), could take place. Such selection could explain the fact that many workers leave the factory after a short time (table 4). Second the upper reference values for the enzyme activities might be too high. In fact our reference group shows a bimodal enzyme activity distribution, which was observed by Rosalki et al (24) too. These 
Table 8. Enzymatic activities and exposure.

\begin{tabular}{|c|c|c|c|c|c|c|}
\hline \multirow[b]{2}{*}{ Subgroup } & \multicolumn{2}{|c|}{ Metabolites } & \multicolumn{4}{|c|}{$\begin{array}{l}\text { Enzyme } \\
\text { ( } \% \text { of "normal" upper limit) }\end{array}$} \\
\hline & $\begin{array}{l}\mathrm{Mol} / \mathrm{mol} \text { of } \\
\text { creatinine }\end{array}$ & $\mathrm{Mg} / \mathrm{g}$ & $\begin{array}{c}\text { Ornithine } \\
\text { carbamoyl } \\
\text { trans- } \\
\text { ferase }\end{array}$ & $\begin{array}{l}\text { Aspartate } \\
\text { amino- } \\
\text { trans- } \\
\text { ferase }\end{array}$ & $\begin{array}{l}\text { Alanine } \\
\text { amino- } \\
\text { trans- } \\
\text { ferase }\end{array}$ & $\begin{array}{c}\text { Gamma } \\
\text { glutamyl } \\
\text { trans- } \\
\text { ferase }\end{array}$ \\
\hline \multicolumn{7}{|c|}{ A1 $[\text { TM } 3 \leqslant 0.292 \mathrm{~mol} / \mathrm{mol} \text { of creatinine }(390 \mathrm{mg} / \mathrm{g})]^{\mathrm{a}}$} \\
\hline $\begin{array}{l}\text { Mean } \\
\text { SD } \\
\mathrm{N}\end{array}$ & $\begin{array}{l}0.114 \\
0.074 \\
30 \\
* * *\end{array}$ & $\begin{array}{r}152.7 \\
98.2\end{array}$ & $\begin{array}{l}59.3 \\
15.4 \\
29 \\
+\end{array}$ & $\begin{array}{l}45.0 \\
14.0 \\
29 \\
\text { NS }\end{array}$ & $\begin{array}{l}38.5 \\
14.2 \\
29 \\
*\end{array}$ & $\begin{array}{l}52.1 \\
39.9 \\
30 \\
\text { NS }\end{array}$ \\
\hline \multicolumn{7}{|c|}{ A2 $[\text { TM3 }>0.292 \mathrm{~mol} / \mathrm{mol} \text { of creatinine }(390 \mathrm{mg} / \mathrm{g})]^{\mathrm{a}}$} \\
\hline $\begin{array}{l}\text { Mean } \\
\text { SD } \\
\mathrm{N}\end{array}$ & $\begin{array}{l}0.544 \\
0.255 \\
18\end{array}$ & $\begin{array}{l}726.2 \\
340.3\end{array}$ & $\begin{array}{l}67.8 \\
20.4 \\
18\end{array}$ & $\begin{array}{l}45.0 \\
15.2 \\
17\end{array}$ & $\begin{array}{l}55.0 \\
36.9 \\
17\end{array}$ & $\begin{array}{l}64.9 \\
40.7 \\
18\end{array}$ \\
\hline \multicolumn{7}{|c|}{ A1 $[\text { MAES } \leqslant 0.818 \mathrm{~mol} / \mathrm{mol} \text { of creatinine }(1,100 \mathrm{mg} / \mathrm{g})]^{\mathrm{b}}$} \\
\hline $\begin{array}{l}\text { Mean } \\
\text { SD } \\
\mathrm{N}\end{array}$ & $\begin{array}{l}0.278 \\
0.244 \\
34 \\
* * *\end{array}$ & $\begin{array}{l}374.0 \\
328.0\end{array}$ & $\begin{array}{l}63.5 \\
20.5 \\
33 \\
\text { NS }\end{array}$ & $\begin{array}{l}45.2 \\
15.4 \\
33 \\
\text { NS }\end{array}$ & $\begin{array}{l}44.6 \\
29.9 \\
33 \\
\text { NS }\end{array}$ & $\begin{array}{l}53.9 \\
38.2 \\
34 \\
\text { NS }\end{array}$ \\
\hline \multicolumn{7}{|c|}{ A2 $[\text { MAES }>0.818 \mathrm{~mol} / \mathrm{mol} \text { of creatinine }(1,100 \mathrm{mg} / \mathrm{g})]^{\mathrm{b}}$} \\
\hline $\begin{array}{l}\text { Mean } \\
\text { SD } \\
N\end{array}$ & $\begin{array}{l}1.842 \\
1.104 \\
14\end{array}$ & $\begin{array}{l}2,477.1 \\
1,485.3\end{array}$ & $\begin{array}{r}62.7 \\
7.7 \\
14\end{array}$ & $\begin{array}{c}43.9 \\
9.2 \\
14\end{array}$ & $\begin{array}{l}44.8 \\
13.5 \\
14\end{array}$ & $\begin{array}{l}70.4 \\
43.5 \\
15\end{array}$ \\
\hline
\end{tabular}

a Metabolic excretion expressed as the average of the total metabolites (mandelic and phenylglyoxlic acid) concentration on day 1 and 2 (TM3). Urine samples taken before the beginning of the workshift. A TM3 excretion of $\leqslant 0.292 \mathrm{~mol} / \mathrm{mol}$ of creatinine $(390 \mathrm{mg} / \mathrm{g})$ corresponds to a styrene exposure of less than $50 \mathrm{ppm}$.

b Metabolite excretion expressed as mandelic acid measured from urine samples taken at the end of the workshift (MAES). An MAES excretion of $\leqslant 0.818 \mathrm{~mol} / \mathrm{mol}$ of creatinine $(1,100$ $\mathrm{mg} / \mathrm{g}$ ) corresponds approximately to a styrene exposure of less than $50 \mathrm{ppm}$.

$* \mathrm{p}<0.05,{ }^{* * *} \mathrm{p}<0.001,+\mathrm{p}<0.10, \mathrm{NS}=$ not significant (Differences between subgroups A1 and A2).
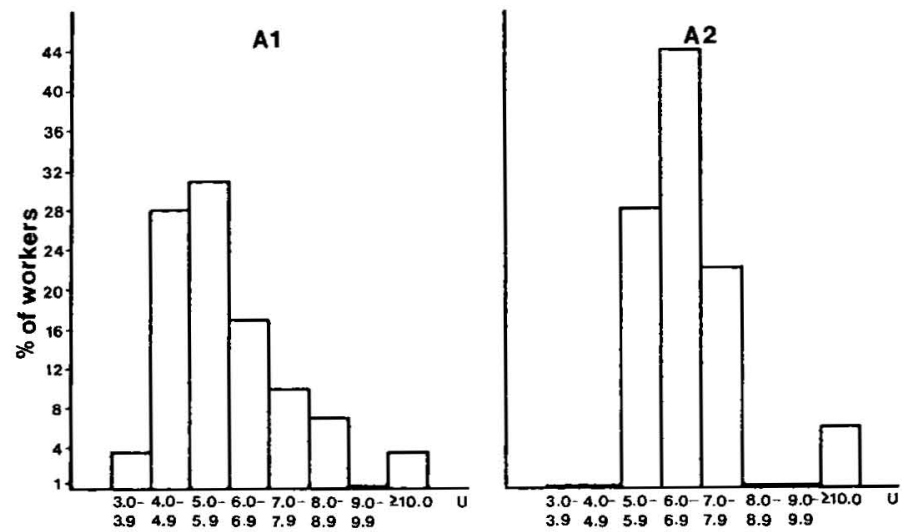

Fig 1. Percentage of workers in each ornithine carbamoyl transferase activity class. [Subgroup A1: styrene exposure below about $50 \mathrm{ppm}$, subgroup A2: styrene exposure above about $50 \mathrm{ppm}$ (details in text)] 
authors think that the higher modality might have resulted from the inclusion of apparently healthy people in whom enzyme levels reflect minor liver damage. In the present study, the enzyme activity distribution of subgroup A1 resembled that of the lower mode of the reference group. We think that the increased activities in subgroup A2 are related to minor liver damage with apparently no clinical trouble. These higher activities in subgroup A2 cannot be explained by alcohol intake, drug consumption, or present liver disease.

\section{Discussion and conclusions}

The correlation between the urinary metabolites and styrene exposure will be interpreted in a future report. It needs only to be noted that the TM3 exposure index is relatively approximate. It would be more appropriate to calculate the average of several determinations throughout the year.

We found that slightly more glucaric acid was eliminated by the exposed workers. If this phenomenon is due to an induction process, the effect is certainly very weak, since there is no correlation between glucaric acid elimination and the length or intensity of exposure to styrene. It should be noted that this slight increase could also be due to our reference values. [Those proposed by Simmons et al (27) would have given no difference]. This difference between our reference values and those given by Simmons et al can quite easily be explained, and we have discussed elsewhere the different causes of error which must be taken into account (lack of truly correct units, slight difference between the regression line of the exposed workers and that of the reference group, possible circadian variations, too few subjects in the reference group, etc). Therefore the biological tests are not biased by autoinduction, and the glucaric acid concentration cannot be used as an exposure index for workers using styrene. Furthermore, it should be borne in mind that glucaric acid is by no means a specific exposure test for styrene.

The question of an assumed hepatotoxic effect of styrene exposure on man cannot be answered yet because further study of reference values is needed and nothing is known about the evolution of enzyme activities in the numerous workers who leave the industry.

The increase of the $\gamma \mathrm{GT}$ activity observed by Lorimer et al (17) could be due to either a "hepatotoxic" or an inductive effect of styrene, since the $\gamma \mathrm{GT}$ is inductible. The glucaric acid elimination and the OCT and ALAT activity measurements seem to confirm that a "hepatotoxic" action occurs.

The Broca index effect tends to lower enzyme activity for fatty people. This phenomenon could be explained by deposition in the adipose tissue and consequently by a decrease in the concentration in the blood, which would be greater for obese than for thin subjects.

The inclusion of the two subjects who were found, in the clinical examination, to be suffering from hepatic or digestive problems, probably not of occupational origin, would increase the tendency described for the hepatic tests. These two workers were in fact in factories where exposure to styrene was important.

Lindström et al (16), on the basis of psychological tests, and Seppäläinen \& Härkönen (26), on the basis of electroencephalographic recordings, arrived at the conclusion that exposure to styrene could have possibly dangerous effects even at concentrations in the ambient air of less than $100 \mathrm{ppm}$. This study arrives at the same conclusion on the basis of hepatic tests. Therefore, a threshold limit value of $100 \mathrm{ppm}$ is not as safe as previously supposed.

\section{References}

1. Colloque international $\gamma$-GT. Apport de la détermination de la $\gamma$-glutamyltranspeptidase à la séméiologie hépatique. Boehringer, Mannheim, France 1973.

2. Erlinguer S, Bohuon C, Gérard-Marchand $R$, Méry AM, Mathé G. Syndrome biologique d'infiltration hépatique au cours des leucémies et hématosarcomes. Soc méd hôp paris 118 (1967) 427-434.

3. Gelehrter TD. Enzyme induction. N engl j med 294 (1976) 522-526, 589-595 \& 646 -651 .

4. Goldberg DM, Martin JV. Role of $\gamma$ glutamyltranspeptidase activity in the 
diagnosis of hepatobiliary disease. Digestion 12 (1975) 232-246.

5. Guillemin M, Bauer D. Human exposure to styrene: II. Quantitative and specific gaschromatographic analysis of urinary mandelic and phenylglyoxylic acids as an index of styrene exposure. Int arch occup environ health 37 (1976) 57-64.

6. Guillemin M, Bauer D. Biological monitoring of exposure to styrene by analysis of combined urinary mandelic and phenylglyoxylic acids. Am ind hyg assoc $\mathrm{j} 39$ (1978) 873-879.

7. Guillemin M, Bauer D, Hotz P, Lob $M$, Greuter WF. Monitoring of styrene exposure in the polyester industry. Scand j work environ health 4 (1978): suppl 2, 14-21.

8. Härkönen H. Styrene, its experimental and clinical toxicology: A review. Scand $\mathrm{j}$ work environ health 4 (1978): suppl 2, 104-113.

9. Hotz P. Exposition au styrène dans l'industrie du polyester: Recherche d'éventuels effets inducteurs et hépatotoxiques. Thèse. Faculté de médecine Lausanne 1979.

10. Hunter J, Chasseaud LF. Clinical aspects of microsomal enzyme induction. In: Bridges JW and Chasseaud LF, ed. Progress in drug metabolism. Wiley Interscience Publication, London 1976.

11. Ikeda $\mathrm{M}$, Ohtsuji $\mathrm{H}$, Imamura $\mathrm{T}$. In vivo suppression of benzene and styrene oxydation by co-administered toluene in rats and effects of phenobarbital. Xenobiotica 2 (1972) $101-106$.

12. Kampmann J, Siersbaek-Nielsen $\mathrm{K}$, Kristensen M, Molholm Hansen J. Rapid evaluation of creatinine clearance. Acta med scand 196 (1974) 517-520.

13. Lambotte-Vandepaer M, Noël G, Rollmann B. Mercier M, Roberfroid M. Modifying effects of styrene on the catalytic properties of some microsomal enzymes. Arch toxicol (1978): suppl 1, 287-290.

14. Lecamwasam OS, Franklin C, Turner P. Effect of phenobarbital on hepatic drug metabolising enzymes and urinary Dglucaric acid excretion in man. $\mathrm{Br} \mathrm{j}$ clin pharmacol 2 (1975) 257-262.

15. Leibman KC. Metabolism and toxicity of styrene. Environ health perspect 11 (1975) $115-119$.

16. Lindström $\mathrm{K}$, Härkönen A, Hernberg $\mathrm{S}$. Disturbances in psychological functions of workers occupationally exposed to styrene. Seand j work environ health 3 (1976) 129139.

17. Lorimer WV, Lilis R, Nicholson WJ, An- derson H, Fischbein A, Daum S, Rom W, Rice C, Selikoff IJ. Clinical studies of styrene workers: Initial findings. Environ health perspect 17 (1976) 171-181.

18. Marshall WJ. Enzyme induction by drugs: Its relevance to clinical biochemistry. Ann clin biochem 15 (1978) 55-64.

19. Nie NH, Hull $\mathrm{CH}$, Steinbrenner $\mathrm{K}$, Bent Dale H. Statistical package for the social sciences (SPSS), 2nd ed. McGraw-Hill, New York, NY, St. Louis, IL 1975.

20. Notten WRF, Henderson PT. The Interaction of chemical compounds with the functional state of the liver: I. Alterations in the metabolism of xenobiotic compounds and d-glucuronic acid pathway. \& II. Estimation of changes in d-glucaric synthesis as a method for diagnosing exposure to xenobiotics. Int arch occup environ health 38 (1977) 197-207 \& 209220.

21. Reichard H. Serum ornithine carbamoyl transferase activity in man, a highly specific test of liver and biliary tract involvement: Observations on 695 patients. Acta med scand 172 (1962) 723-738.

22. Richterich R, Colombo JP. Klinische Chemie, 4th ed. S. Karger, Basel 1978.

23. Rollason JG, Pincherle G, Robinson D. Serum gamma glutamyl-transpeptidase in relation to alcohol consumption. Clin chim acta 39 (1972) 75-80.

24. Rosalki SB, Rau D, Lehmann D, Prentice M. Determination of serum $\gamma$-glutamyltranspeptidase activity and its clinical application. Ann clin biochem 7 (1970) 143 $-147$.

25. Ryan AJ, James OM, Ben-Zvi Z, Law FCP, Bend JR. Hepatic and extrahepatic metabolism of ${ }^{14} \mathrm{C}$-styrene-oxide. Environ health perspect 17 (1976) 135-144.

26. Seppäläinen AM, Härkönen $H$. Neurophysiological findings among workers occupationally exposed to styrene. Scand j work environ health 3 (1976) $140-146$.

27. Simmons CJ, Davis M, Dordoni B, Williams R. Urinary D-glucaric acid assay by an improved enzymatic procedure. Clin chim acta 51 (1974) 47-51.

28. Szasz G. Reaction-rate method for $\gamma$ glutamyl-transferase activity in serum. Clin chem 22 (1976) 2051-2055.

29. Zender R, Falbriand A. Analyse automatique de la créatinine dans le sérum et dans l'urine. Chin chim acta 12 (1965) 183190.

30. Zielhuis RL. Systemic toxicity from exposure to epoxy resins, hardeners and styrene. J occup med 3 (1961) 25-29.

Received for publication: 4 March 1980 